\author{
Victor L. Shammas \\ University of Oslo; Oslo Metropolitan University
}

\title{
The Perils of Parole Hearings: California Lifers, Performative Disadvantage, and the Ideology of Insight
}

Following a series of transformative political and legal battles, California's

overcrowded prison system has moved in the direction of moderate decarceration. A softer stance on punishment means that thousands of previously ineligible inmates serving indeterminate sentences are now being considered for release on parole. Drawing on ethnographic observations of twenty parole hearings in one California men's prison, this study outlines how rehabilitation has come to be enmeshed in a logic of punitivity, as parole commissioners subject inmates to an individualizing gaze that misrecognizes the socially embedded nature of their performance. Parole commissioners are tasked with assessing dangerousness, deploying a multifaceted conception of risk that combines formalized actuarial instruments and evaluative judgments to form the inchoate and contradictory notion of "insight." Inmates are expected to demonstrate this if they are to be released, but what is insight? Parole boards assume that it is a valid indicator of future behavior and probable recidivism, and parole commissioners posit that successful inmates will be capable of demonstrating authentic remorse and 
insight, unimpeded by the constraints of an austere and dangerous carceral environment. However, the discretionary criteria established by the penal system are limited by the deleterious living conditions established by this same penal system. [parole, sentencing, prisons, risk assessment, hyperincarceration]

"You did OK in a controlled environment," the commissioner said to the inmate ${ }^{1}$ sitting across from him. The inmate was one of thousands of inmates sentenced to life with the possibility of parole — or an indeterminate life term —in a California state prison. Clad in the light-blue garb that is the standard outfit for a California prisoner, and surrounded by two correctional officers, the inmate looked increasingly uncomfortable. His parole hearing had taken the better part of three hours and was drawing to a close. A prosecutor from the District Attorney's (DA) Office had presented an explosive final statement that seemed to knock the wind out of the defense: the inmate continued to pose a "current unreasonable risk of danger to the public," the prosecutor had said, because the inmate had not "really explored why he committed so many different crimes with so many different victims [and] with such violence." On the opposite end of the table, the stateappointed defense attorney, sluggish and haggard-looking, had made a closing statement that seemed, if anything, to weaken the inmate's case for early release. 
He had noted the inmate's "extensive" criminal record while attempting to extract some modicum of positive characterization from the almost wholly damning clinical evaluation that had been penned by a board-appointed psychological evaluator.

After a fifteen-minute recess, during which the two-member parole board deliberated in privacy behind closed doors, the hearing resumed. A palpable tension filled the air. After decades spent behind bars, would the inmate at last be granted his freedom? "We're not assessing whether you can be a good inmate and whether you can follow the rules in prison," said the commissioner. "We're wondering: How are you going to do back in society?" The commissioner admitted, "It looks like you are making the right choices and doing the things that make us comfortable." The inmate was "programming," that is, participating in a variety of self-help classes and rehabilitative programs, including Alcoholics Anonymous and Alternatives to Violence. Here the inmate had learned, in his own words, a "lot of things in reference to who we are, who we were" and "the deal about being a slave to alcoholism, about it being ritualistic." These efforts had resulted in a number of laudatory and beneficial "chronos" (chronological) entries placed in the all-important C-file, which was the prison system's computerized central file that documented each inmate's behavior throughout the long years spent circulating in and around the state's sprawling prison system. 
Despite taking such steps, however, the inmate was still not ready to "get a date," in the commissioner's words, and he would not be getting a parole date today. "You have some work to do and we encourage you to stay involved in your programming, making good choices," the commissioner intoned.

To a seasoned observer, the inmate's denial was hardly surprising. This was the inmate's initial parole suitability hearing, which meant that it was only his first time before the Board of Parole Hearings (hereafter, the board), and most lifers were only released, if they were released at all, after appearing before the board for a subsequent parole suitability hearing —often multiple times stretched across multiple years, if not decades.

Reciting the ritualistic phrases that there still existed a "nexus to current unreasonable dangerousness," the commissioner suggested that releasing the inmate would create untenable "potential risks to society." First, the inmate's risk assessment report, produced by the board's own Forensic Assessment Division, had determined that the inmate posed a "moderate" risk of violent behavior. Moderate, the commissioner said in a matter-of-fact tone, "is not good. Moderate is not bad. It is in the middle." Another actuarial instrument, the Static-99, used to assess the risk of recidivism among male sex offenders, showed a "moderatehigh" risk. Also, the inmate's Hare Psychopathy Checklist-Revised (PCL-R) 
score was "above the mean of North American male inmates." Second, the inmate had failed to offer appropriate "insight," a multifarious and inchoate category denoting a satisfactory expression of knowledge about the motives and causes of a "life crime" (i.e., the crime for which a "lifer" has been sentenced to life in prison). As Wattley (2013) notes, the concept of "insight" is crucial to parole commissioners and, indeed, the wider board. One telling example is that in the official transcripts of the twenty hearings observed in this study, the term "insight" on average appeared more than seven times per hearing, for a total of 141 mentions.

"Some of your self-exploration that you have done still causes us some pause," the commissioner said with a concerned look. Finally, the inmate had broken a number of important prison rules: on two occasions he had been caught drinking "pruno," an illicit form of alcohol manufactured by some inmates in their cells. The inmate admitted to drinking it, and the commissioners thanked him "for being forthcoming." Such honesty, said the deputy commissioner, was "a good thing" because it was a sign of a "prosocial attitude," before he added, almost as an afterthought: "Do you know what that means?" The inmate timidly replied yes. Moreover, a routine search had uncovered a cell phone among the inmate's belongings. Such behavior, the prosecutor from the DA's Office noted in their closing statement, evidenced the inmate's "mental state today." The prosecutor 
believed the inmate was duplicitous and dangerous, "where he minimizes and tries to make himself look better."

Admittedly, the pruno incident was nearly a decade ago and the cell phone episode was almost five years in the past. Nevertheless, by the weight the commissioner appeared to attribute to these acts, they seemed, felt, and were perceived as far more recent. Time passed more slowly in prison than it did on the outside and seemed to be evaluated along a compressed time-scale. "Lifer-time" was both experienced as passing more slowly than time on the outside — described by Medlicott (1999) as the "pains of prison time"-and it was deemed less worthy by the board in comparison with "outside-time": a lifer-year was decidedly not equivalent to an outside-year.

In short, the board had reviewed all the available evidence: psychological evaluations, disciplinary reports, vocational qualifications, therapeutic programs, and parole plans. For this initial hearing, the sum total of these impressions was not enough to make the board feel "comfortable." They admitted that the inmate was an "articulate guy" who was able to explain himself "pretty well." Eloquence, however, while important for facilitating the appropriate level of "insight," could also be negatively construed as a mark of evasion and falsity: the board had the power to decide whether expressions of remorse were authentic indicators of self- 
knowledge and regret, or whether they were the duplicitous marks of a hardened criminal. Summarizing the board's judgment, the commissioner outlined a range of sanctions available to them:

So did you present well today? You did. Are you a smart guy? You are. You doing good things? Yes. Are you ready to go home yet? We don't think so. So we are required to start at a fifteen-year denial, but we didn't make it a fifteen-year denial for you. You are doing the right things, like I said. So we looked at a ten-year denial, and we felt a tenyear denial was inappropriate for you, too, because you are at an age that reduces the probability of recidivism. So then we looked at a seven. We looked at a five, and we looked at a three-year denial. We gave you a three-year denial, which was the lowest we can give you.

This was their verdict, then: to remain in prison for another three years. "You have some work to do," the commissioner said, "and we encourage you to stay involved in your programming, making good choices." Accompanied by two guards, the inmate rose listlessly and shuffled back to a holding cell just outside the hearing room. Another three years of waiting, keeping out of the way of the many prison gangs that sliced and diced the prison yard into their multifarious territorial domains, resisting the dangers of solitude and desperation, keeping 
abreast with "programming" and whatever classes and training programs were on offer, and working to appease the board lay before him. Three hard years.

This study draws on ethnographic observations of twenty parole hearings that took place in one California state prison over a period of nine months in 2015 and 2016. The hearings took place inside the prison itself. In addition, the author attended five meetings by a legal aid clinic in Northern California that offered assistance to inmates in preparation for their parole hearings; five monthly executive board meetings by the Board of Parole Hearings in Sacramento, California; interviewed three defense attorneys, two prosecutors, and one legal aid organization; and engaged in informal conversations with dozens of defense attorneys, prosecutors, prison officers, parole commissioners, legal experts, and activists - mainly in the many breaks that invariably took place during the parole hearings.

All of the offenders in the sample were serving indeterminate life sentences. The minimum lower-bound sentence length was fifteen years to life (or more simply, "fifteen-to-life") and the maximum was one hundred-to-life. The most frequent sentence was the former, with six out of twenty inmates serving such a sentence. Many inmates appeared old, frail, and worn-down by long years spent behind bars: nine out of twenty inmates had been confined since the 1980s, and ten had 
been admitted to prison in the 1990s. One should be careful to note that many offenders had been convicted of serious crimes. The majority of inmates were convicted of murder: five were serving sentences for first-degree murder while twelve had second-degree murder as their "controlling offense." Some were serving time with extensive conviction records. One inmate with a very extensive rap sheet - including Kidnapping (two counts), Robbery (four counts), Robbery and Ransom, Use of a Firearm, Oral Copulation in Concert, Rape and Resistance with Force, Sodomy in Concert, Use of a Firearm, Vehicle Theft, and SecondDegree Burglary_took the opportunity to "stipulate," that is, waive the right to a hearing, for five years, rather than face the risk of a seven-, ten- or fifteen-year denial. Only one inmate was a "third-striker," which is a person convicted under the California Three Strikes law, introduced in 1994; this raises the level of punishment for successive felony convictions (Zimring, Hawkins, and Kamin 2001). A first strike is incurred when convicted of a "serious felony." If the person is later convicted of a second "serious felony," the person receives a second strike and the sentence length for that crime is automatically doubled. If the same person is later convicted of a "serious or violent" felony, they receive a mandatory twenty-five-year-to-life sentence. Between 1994 and 2013, any felony conviction would result in a third strike; following the enactment of Proposition 36 in 2013, however, this was revised to include only "serious or violent" felonies (Couzens and Bigelow 2017, 5). 
Far more prevalent in this study were various sentencing enhancements, such as "Use of a Firearm," which raised the minimum thresholds of the indeterminate life sentences for nine of the inmates who participated in the hearings. Sentencing enhancements are legal modifiers that increase the amount of punishment ordinarily meted out for a crime depending on various circumstances, including whether an offender used a firearm in the commission the crime, as with the "tento-twenty-life enhancement" (also known as "use a gun and you're done"). This can result in an additional and consecutive ten-, twenty-, or twenty-five-year-tolife mandatory sentence.

In keeping with the disproportionate ethno-racial composition of the California (and wider US) prison population, fully 90 percent of the observed inmates were non-white: twelve inmates were black (60 percent), four were Hispanic (20 percent), two were Asian (10 percent). Two inmates were white (10 percent).

Meanwhile, 25 percent of the hearings observed in this study resulted in a parole grant; 20 percent were waived (by inmates) or postponed (by the board); and 55 percent resulted in a denial of parole, ranging from three-year denials (36 percent of denials), to five years (18 percent), and to seven years (63 percent). There were no ten-year or fifteen-year denials, even though in 2015 they made up more than 5 
percent of all denials in California. The commissioners observed in this sample made less frequent use of three-year denials (36 percent versus a systemwide rate of 59 percent) and five-year denials (18 percent versus 26 percent) and more frequent use of seven-year denials (63 percent versus 9 percent). Commissioners were in some sense therefore both more and less punitive: their grant rate was more liberal than the board viewed as a whole ( 25 percent versus 17 percent in 2015). The length of their denials, while avoiding the longest denial available on the penal menu, made disproportionate use of seven-year denials. This contradictory quality can perhaps be explained by the perception of the prison as, on the one hand, housing inmates who are among the "worst of the worst," while, on the other hand, being reputed for making volunteer-run rehabilitative programs widely available to inmates that could facilitate a "decent performance" in hearings.

The bulk of the material deployed in this article is derived from observing the parole hearings as they unfolded, documented in ethnographic fieldnotes and official transcripts. Fieldnotes were composed during the hearings and immediately thereafter. The analytic approach to this documentary record was that of immersive reading, consisting of repeated readings of the notebooks containing handwritten fieldnotes and printed copies of the transcripts and repeated returns to the same texts to generate a sense of "deep immersion" 
(Emerson, Fretz, and Shaw 2011, 14). This form of reading in turn facilitated a form of coding in which repeated themes were written out under analytic headings in a separate document. What is striking about these parole hearings is how monotonously repetitive they became over time, how so many of the same lines were rehearsed and repeated: in short, how homogeneous much of the material remained, a fact no doubt owing to the ritualistic nature of such legal proceedings.

Hearings were selected by the author from a roster that displayed upcoming hearings at one men's prison in the California prison system, and requests for observation were sent to the board. However, requests were routinely denied. While hearings, like court trials, are in principle open to the public, ethnographic access was circumscribed in various ways: the sample of observed hearings is a convenience sample, but one that was convenient from the perspective of the California Department of Corrections and Rehabilitation (CDCR), usually (or so the author was told) on the basis of available staff to ensure the provision of a safe environment. One limitation of observing hearings in one prison alone is that California state prisons offer an uneven level of rehabilitative programming. However, the geographic concentration of the sample was counteracted by the fact that the author was able to observe ten out of the state's twelve commissioners at the time (due to their geographically rotating schedules) and inmates who had previously served time in a broad range of facilities up and 
down the state of California; and both observe and speak to prosecutors from a range of counties beyond the area in which the prison was located, owing to the wide geographical distribution of crimes that had resulted in the inmates' terms of incarceration.

\section{Transforming Penality}

At the beginning of 2014, more than 32,000 lifers were incarcerated under the auspices of the CDCR, constituting nearly 25 percent of the total inmate population held in California's state prisons (CDCR 2014). Around 4,700 of these inmates were sentenced to "life without the possibility of parole," a true life sentence. The remaining lifers were confined on indeterminate life sentences as described above. Inmates serving indeterminate life sentences have the right to appear before a parole board to determine whether they pose an "unreasonable risk of danger to the public" (CDCR 2016). Between the late 1970s and the early 2010s, an indeterminate life sentence in California usually entailed incarceration for the remainder of the inmate's natural lifespan, and to appear before the board was to face the almost certain prospect of denial. More than 2,100 suitability hearings were scheduled in the year 2000 alone throughout the state of California, but only 52 inmates were granted parole that year. Between 1990 and 2000, the board's denial rates for all statewide scheduled lifer hearings ranged between 95.9 percent and 99.6 percent. Those few inmates who found themselves granted 
parole faced the nearly inevitable prospect of the governor's reversal of those decisions. This was based on Proposition 89 (1988), which allowed the governor the right to "affirm, modify or reverse" parole decisions for inmates convicted of murder. $^{2}$

This did not, however, stop the board from holding thousands of hearings every year starting in the mid-1990s. As one defense attorney told me of this period, lifers were "told by other lifers in prisons all over California, it's useless, it's a totally futile exercise, don't even bother." Show trials—or rather show hearingswere spectacles of procedures and legal fairness. These were oblivious hearings, that is, hearings but without listening. When an inmate's plea for release was heard by the board, the governor stood ready to block that release. Between 2003 and 2010, Governor Arnold Schwarzenegger reversed around 75 percent of the board's parole grants. ${ }^{3}$ Meanwhile, a California Supreme Court ruling in 2002 required the governor to present "some evidence" of an inmate's unsuitability for release before denying the board's decision to grant parole; however, this legal requirement was typically met by referring to the "egregiousness of the crime" for which the inmate had been incarcerated (Hipolito 2009). Since most lifers had committed violent crimes that could be construed as egregious, this legal standard was relatively easy to meet, so the denials and reversals of parole continued unabated. 
By the early 2010s, a series of legal, political, fiscal, and cultural trends coincided to markedly improve the prospects of release (Weisberg, Mukamal, and Segal 2011). In this period, "everything changed," one defense attorney told me. "Lifers had hope." Court decisions contributed to paring down the state's prison population. In Brown v. Plata, the United States Supreme Court affirmed a courtmandated reduction of the state's prison population to 137.5 percent of design bed capacity (Simon 2014). ${ }^{4}$ Multiple legal rulings and legislative acts benefited California's lifer population (Wattley 2013). Following In re Lawrence, ${ }^{5}$ the California Supreme Court affirmed that parole denials were to be related to the purported "current dangerousness" of an inmate and could not solely reference “egregious" past crimes (Sarosy 2014). In another case, In re Shaputis, the California Supreme Court reiterated the importance of present-day risk, opining that the "essential question in deciding whether to grant parole is whether the inmate currently poses a threat to public safety." Assessing dangerousness would be made on the basis of at least three sources of knowledge: "the facts of the offense, the inmate's progress during incarceration, and the insight he or she has achieved into past behavior." ${ }^{16}$ State legislation allowed lifers who had committed their "life crime" at a young age to receive special consideration for release. Passed in 2013, Senate Bill 260 extended this right to those convicted of crimes while under the age of eighteen. It was followed the next year by Senate Bill 261, 
which enlarged the scope of youth hearings to those who had committed their crimes while under the age of twenty-three.

The cumulative effect of these events was to soften the board's stance. Increasing numbers of lifers were granted parole. Following the election of Governor Edmund G. Brown Jr. in early 2011, only around 20 percent of the board's parole grants for convicted murderers were reversed. This reduced propensity to reverse the board's decisions represented an almost complete inversion of Governor Schwarzenegger's policy of parole reversal. By 2014 the number of lifers granted parole by the board over the course of that year alone - 902 persons - exceeded the total number of lifers granted parole over the course of more than two decades: only 750 lifers had been released between 1978 and $2001 .{ }^{7}$ A report on the minuscule recidivism rates of released lifers seemed to solidify the momentum driving increased lenience toward lifers (CDCR 2013a). A released cohort of California lifers was found to have a three-year reconviction rate of 4.8 percent (against a 51.5 percent recidivism rate for released offenders with determinate sentences). While the questionable methodology of the report did not accurately capture the probable recidivism rate of the total lifer population in California state prisons, it seemed to announce a novel willingness to consider lifers in a favorable light. Emanating from within the correctional bureaucracy, the state itself had produced a technical account that seemed to support the case for parole grants. 
Nevertheless, these limited reforms were still embedded in a regime of hyperincarceration. This term is preferable to the more widely used mass incarceration because, as Wacquant (2010) points out, the US penal system is not truly a "mass" phenomena in the style of, say, the "mass media." It does not impact all citizens equally. Instead, it targets a spatially, ethno-racially, and socioeconomically skewed sample of the population: poor, urban, and black or brown bodies.

Lenience remained modest; nearly 70 percent of lifers who appeared before the board in 2015 were denied parole (Board of Parole Hearings 2016a). An influential advocacy group elaborated the alleged dangers of releasing lifers; for example, the executive director of the Crime Victims Action Alliance, Christine Ward, was quoted during a news segment: "This is playing Russian roulette with public safety," and the board's "change of philosophy" would be "dangerous" to the state's inhabitants (Elias 2014). Amid such anxieties, a handbook published by the CDCR directed at crime victims and their families reassured its readers: "Inmates sentenced to life with the possibility of parole are not guaranteed parole and can be held in prison for life" (CDCR 2015, 2). More were getting out, but most were still locked up. 


\section{Embedded Rehabilitation}

One prominent strand of thought in the sociology of punishment has posited a dichotomy between rehabilitation and punitivity (e.g., Garland 2001).

Rehabilitation is equated with tolerant penality while the absence of rehabilitation is taken to be a mark of retributive punitivity, and declining investments in rehabilitation are said to herald the improving fortunes of punitive politics. This conceptual couplet has been adopted by a wide range of scholars. Garland (2001) proposes that the waning fortunes of a regime variously labeled "penal modernism" or "penal welfarism," premised on faith in the corrigibility of deviant subjects by science and the state, was supplanted by a culture of control, a "new crime control agenda" was launched and agents (successfully) set out to "rob rehabilitation of its appeal and tilt the balance of opinion against it" (64). For Wacquant $(2009,145)$ increasingly punitive parole procedures in California from the 1970s and onward were the result of the "jettisoning of the ideal of rehabilitation" in a period when rehabilitation was "effectively replaced by a managerialist philosophy." Ward and Maruna (2007, 8-9) seamlessly conflate Martinson's (1974) work on "What Works" with the resurgence of punitivity, asserting that the latter helped "usher in an era of 'nothing works' pessimism with 'lock-'em up' punitiveness.' Similarly, Beckett and Western $(2001,38)$ contend that beginning in the 1960 s the "rehabilitative project was called into question," suggesting that its diminution was instrumental in the subsequent promotion of 
the "goals of incapacitation, deterrence and retribution." In the comparative penology of the United States and Western Europe, nonretributive societies are said to mobilize comprehensive rehabilitative programs, while highly punitive societies are characterized by a dearth of rehabilitation (e.g., Downes 1988). Penal excess is characterized by a lack of rehabilitation, which is penal exceptionalism by its very prominence.

While Ward and Maruna (2007) have undoubtedly sharpened much analytic work by allowing observers to attend to essential features in crowded empirical landscapes, such analytic profits come at the cost of theorizing rehabilitation in overly static terms while ignoring its recent reconfiguration (Robinson 2008). Rehabilitation is often embedded in punitivity. Far from being mutually incompatible entities, rehabilitation and punitivity may intermingle in an unstable admixture (Goodman 2012). Rehabilitation and retributivism "relate to each other as reforms, not as steps away from brutality or inconsistency, but as attempts to make prisons produce social stability through applying some mix of care, indifference, compulsory training, and cruelty to people in cages" (Gilmore 2007, 14). Beyond acknowledging that highly punitive societies may employ a particular language of treatment that tends to reduce rehabilitation to mere rhetoric (e.g., Lynch 2000), this therapeutic language may also be enmeshed in punitive practices. The polysemy of rehabilitation allows it to malleably insert 
itself into the cracks of the punitive edifice, fusing with harsh justice, strict sentencing, and carceral austerity. The obverse may also be the case: punitive practices are liable to be inserted into the cracks of therapeutic or rehabilitative edifices. Notably, this has been observed in the case of the Scandinavian regimes of punishment, lauded for a humane form of "penal exceptionalism," particularly in their minimum-security and rehabilitation-oriented "open" prisons, where novel modalities of suffering have made themselves felt within a system of rehabilitation, described as "pains of freedom" (Shammas 2014).

Thus, when inmates say they have participated in Alcoholics Anonymous (AA) or Narcotics Anonymous (NA) programs, commissioners may test inmates, poking and prodding at their accounts by interrogating their knowledge of the individual steps in these twelve-step programs:

Deputy Commissioner (DC): Do you work the steps?

Inmate:
been through them already once_-but I have
a certificate there for that completion.
DC:
Inmate:
DC:


What have you put in your inventory?

Inmate: $\quad$ In my inventory—you know, really getting to know yourself.

DC: $\quad$ Okay. What have you put in your inventory. [With growing irritation.] I'll ask you a second time.

Inmate: $\quad$ I don’t understand.

The deputy commissioner believed there was a mismatch between the inmate's "performance" and his record of participation in programs such as Victim Awareness, NA, and AA. Inmates who undergo rehabilitation are usually said to be programming. Sometimes there is a degree of slippage in the usage of these terms, so that programming is variously described as something one does or something one undergoes. "You started participating in programming," one deputy commissioner said approvingly to an inmate. This seemingly innocuous phrase aptly encapsulates the traditional critique of rehabilitation as involving the imposition of normalizing standards of cognition and behavior. It is almost chillingly cybernetic. Inmates who are participating in rehabilitation are programming or being programmed, as if they consisted of so many lines of defective code to be rewritten by social (software) engineers or as if they themselves were the engineers of their own script and were capable of debugging 
their internal syntax. In discussions of rehabilitation, inmates are subjected to a moralizing-individualistic category of perception and action premised on the twin notions of a self-determinate optimization of the self (or "bootstrapping") and an antistructuralist and false autonomization of individuals caught in noxious milieus and captured by deleterious social configurations. This hybridized configuration of rehabilitation and punitivity (O’Malley 1999)_forged “not to punish less, but punish better" (Foucault 1995, 82) — is imbued with the aura of social legitimacy, being more closely aligned with the spirit of an age.

There are two primary sources of extra-individual power that introduce conditions of heteronomy on inmates engaged in so-called rehabilitative programming. First, inmates must be able to participate in these programs; that is, programs must be made available. However, not all prisons are equipped for this. Some institutions operate numerous programs and enjoy a great influx of volunteers while others are almost devoid of such opportunities. The expectation that someone will have completed such programs is an expectation directed at the individual inmate, but it should be mediated through the opportunities extant in the institutional environment. One deputy commissioner complained that an inmate had not participated in enough rehabilitative programming and asked whether the inmate had given any thought to transitional housing in the event of his release from prison. However, the inmate had spent more than two decades in a security 
housing unit (SHU) in a maximum-security facility prior to arriving at his current institution.

"I really don't know much about it because they never gave us any of that stuff," the inmate replied. This response met with resounding disapproval in the deputy commissioner's closing statement and was made the object of savage scorn.

The deputy commissioner lectured the inmate: "You really don't have a relapse prevention awareness. You are in many ways not a grown-up man," said the deputy commissioner. "You lack self-sufficiency. Your plans include just being parasitic as soon as you get out, [by] living with somebody." The inmate was minimizing because the right type of "programming hasn't been done yet." It did not matter that panel recognized that this was due to circumstances beyond the inmate's control.

“In fairness to you, you've been in SHU for 26 years and without a lot of access to programming," said the commissioner. Even this admission, however, was tempered by the commissioner's suggestion that "one of the benefits" of residing in a SHU—where individuals are isolated from almost all human contact in a state of mind-numbing monotony likened to torture (Amnesty International 2012) was that "you don't have an opportunity to interact with anybody." Therefore, the 
inmate could remain free from "violent interactions with anyone." Institutional parameters were reduced to individual performance; in this performance (in the Austinian sense), a real condition of heteronomy was denied while a condition of autonomy was artificially posited.

When another inmate recounted that he enjoyed playing dominoes and working in the prison kitchen, the deputy commissioner immediately signaled his disapproval of inadequate programming: "Any vocational or self-help at this time?"

The inmate replied, "No, I didn't have a strong interest in it at the time," before quickly adding, “There weren't many programs, and we were on lockdown for most of the time." This last response drew a sneer from the commissioner, who strongly disliked inmates that rationalized a lack of programming by way of institutional inadequacies. Inmates were presumptively wrong or negligent because there was always something they could have done to correct their ways.

Second, inmates must be able to communicate that they have meaningfully participated in such programs. On the one hand, this means placing before the panel a document, diploma, certificate, score, letter of recommendation, or other piece of evidence confirming the inmate's participation in rehabilitation. However, prisons are complex bureaucracies; they are often chaotic, underfunded, 
and poorly equipped, barely squeaking by with subpar technological infrastructure where information is routinely lost or misdirected. Inmates lack resources and capacities to pursue their cases in an uninterested or hostile environment. One inmate was falsely accused of having been arrested thirty-nine times and convicted of six prior felonies - a damning criminal record that would certainly impede the chance of being granted parole - which ultimately turned out to be an artifact of bureaucratic error. After much discussion back and forth, the commissioner was finally forced to concede, "We could not find the thirty-nine arrests that are noted in the record." The inmate, previously frightened by this potentially damning assertion, looked visibly relieved.

On the other hand, written certification is not sufficient evidence of personal transformation. Inmates must communicate what they have learned from the program in ways recognized as legitimate. One deputy commissioner denied the validity of an inmate's rehabilitative process: "I'm trying to understand your violence," said the deputy commissioner said. "It's good that you've started, it's a long process." This was tantamount to saying, only halfway through the hearing, that the inmate was not likely to be granted parole. "You've got some buzzwords," the deputy commissioner continued, a damaging devaluation of the inmate's labor of self-improvement. The offering of written evidence of programming was not enough; it was also necessary to present programming 
buzzwords in a manner that seemed authentic and unscripted.

Religious faith is often viewed by the board as a proxy of pacification and introspection. The same inmate was praised for his involvement in a religious community, but when the panel discovered that he had switched different religious denominations while in prison and had engaged in an activity considered incompatible with the tenets of the latest religious affiliation-eating a hamburger - the panel grew skeptical. "I see you had a hamburger in 2009," the deputy commissioner said. "It's not the crime of the century, but I want to see where you're at in terms of your faith." Such minor acts are construed as indicators of insincerity, which could be used as a proxy for an inmate's continued dangerousness. As Foucault (2003) observed, the psychologization of legal proceedings shifts the object of punishment from crime to character. It is not so much the criminal offense that is being sanctioned as the person's aberrant aspects (17).

Inmates must be able to talk about how they have been transformed by rehabilitative interventions. If they are unable to speak persuasively about these experiences, their participation is liable to be denied and devalued. However, these expectations hinge on a personal capacity to (1) verbally express thoughts and feelings, (2) speak in a reflective manner, and (3) produce linguistic 
utterances in a socially legitimate form. All three capacities are nonuniversally allocated; they are unevenly distributed according to properties such as socioeconomic class, educational attainment, and mental and physical health. Ultimately, then, even a pragmatist acceptance of the normalizing tendencies inherent in the rehabilitative agenda must contend with the problem of participation and verification. To become a rehabilitated subject means, doubly, having participated and having been verified. Participation depends on a particular extra-individual, institutional configuration that is beyond the control of the individual agent, while verification is subject to utterances, dispositions, and capacities that are unevenly distributed in social spaces. It is the expectations of participation and verification that forms the basis of the notion of insight.

\section{Individualized Performances}

As the board's central "principle of vision and division" (Bourdieu 1998b, 53;

2014, 164-67), the notion of insight fundamentally structures the day-to-day operations and decision making in parole boards across California (Wattley 2013). ${ }^{8}$ This nebulous term mandates that inmates demonstrate a capacity to speak about criminal behavior in a way suggestive of a reformed subject who is capable of avoiding criminality in the future. The notion of insight has come to constitute a multivalent, polysemic, and conflicted symbolic category because it requires: blending the capacity to perform with particular standards of evaluative judgment, 
possessing an institutional record free from serious rules violations, proving participation in rehabilitative programming, and holding a low risk score from the board's psychological evaluators. Insight has a fundamentally individualizing thrust that allows parole power to focus the operations of multiple external agents and agencies - prison guards, psychologists, pedagogues, rehabilitation volunteers, and others - on a single individual while simultaneously construing the inmate's performance as the work of an atomistic, isolated agent.

This individualizing reduction denies the embeddedness of performances in legal procedures, which in actuality are coproduced by exterior flows of social power beyond the ambit of individual personhood (Valverde 2003). This reduction of socially embedded reality to an atomistic state amounts to what Hegel called the positing of the "being of the individual" as "the primary and the supreme thing" (quoted in Honneth 1995, 12), a fallacy typical to practitioners of the law. Lifers are socioeconomically and ethno-racially marginalized. Approximately 70 percent of California lifers are black or Hispanic (Nellis 2013, 9-10) and are disproportionately drawn from the lowest rungs of the class structure (Wacquant 2009; Western 2006). This gives rise to a form of devalorized speech and a failure to speak in accordance with legitimate language (Bourdieu 1991), which necessarily results in a situation of performative disadvantage. 
In essence, inmates must be able to show why their crimes occurred; that is, to produce causal accounts of the crimes and to show how those causes have been curbed by a labor of self-improvement. If anger is seen to be a cause of their history of violent crime, for instance, inmates must be able to demonstrate an ability to control their emotions, which must in turn be validated by participation in programs such as anger management classes and "clean" prison records. If gang membership is considered a central cause of their "life crime," a record demonstrating freedom from entanglements with prison gangs could be suggestive of appropriate levels of insight. One inmate, when asked by a deputy commissioner to define insight, answered: "I have some type of understanding of why things happened." A commissioner deployed the term to refer to a knowledge of "causative factors," and used it as grounds for denial of parole to one inmate (as indeed most commissioners do when making denials):

This insight issue, it's a concept. There's no such thing as perfect insight. But more insight is required than what you were able to demonstrate today. Everyone in this room agrees you had a horrible childhood. We know that. But the hard work about saying well, how does that affect me and how does that translate into my extreme rage and my issue of anger and violence against women. 
As all social scientists know, it is inherently difficult to produce causal accounts of human actions. University libraries around the world are filled with the written records of those methodological struggles waged over the place of causality in the human sciences. The pragmatic-realist epistemology of the board demands the production of what it considers sufficient accounts of criminal causality with the aim of predicting and avoiding the repetition of crime. In one hearing, a commissioner considered an inmate's explanation of his crime - a gang-related murder - to be wholly unimpressive. Summarizing the inmate's account, the commissioner said the reasons offered for the murder essentially came down to the inmate feeling "threatened," the fact that his victim was a "rival gang member," and that there was "always rivalry" between the inmate's gang and the gang of the victim. In the given situation, the commissioner explained, "One of the guys standing by the door had his hands in his pocket," giving the inmate reason to believe his victim "had a weapon." This account left the commissioner cold. The inmate "gave some very superficial reasons for this crime" that were said to show a "lack of insight." Lacking insight is a damning indictment.

Producing sufficiently deep accounts is necessarily difficult, partly due to the constraints of epistemic uncertainty. On the one hand, there are the asymmetries of information that exist between parties - what economists call "imperfect information" - and, on the other hand, there are the constraints of informational 
scarcity that hamper efforts to produce rich accounts of past events. Inmates are asked to recall large amounts of information about their life crime, but the events lie decades in the past, thereby becoming subject to memory slippages or even involuntary acts of repression. Inmates are often unable to study the extensive paperwork detailing their case, and they may have developed rationalizations to survive institutional life during long decades spent in prison when release seemed like_-and, objectively speaking, really was — an impossibility. On the opposite side of the table, the commissioners and prosecutor have access to the documentary record with the touch of a few buttons on their computer. Strangely, then, an inmate may speak less convincingly about the experiences of his own life - the commission of the crime and its circumstances and causes - than complete strangers who were never there but who have crucial access to his case file. Another inmate was told by a commissioner that he was not required to "admit to the life crime." While strictly speaking true in the legalistic senseinmates have the de jure right to maintain their innocence-maintaining innocence will always de facto result in a denial of parole. It is nearly impossible for an inmate to "show insight, remorse, the sort of mindset that a panel wants to see," in the words of the commissioner, when he does not admit his guilt. Admissions of guilt, demonstrations of self-knowledge, and the appearance of pacification and self-reform are intimately interwoven. In this case, the inmate had failed to "accept responsibility" for the crime. The commissioner said: 
And that's even after he has taken courses in denial management, in criminal thinking, victims impact, substance abuse. These are courses, all of which should have helped him gain further insight into these areas of concern. But reading the Psych Report, which is just a couple of months old, there's reason to question whether or not he's fully internalized what he's gotten out of those courses. So we would certainly urge him to go back and revisit some of his coursework, take a look at his life, figure out where he went wrong, the decisions that he made, what the foundation for those decisions were.

Participating in rehabilitative programs was not enough—successful programming was the necessary precondition for learning how to express the transformative effects these programs had on the inmate himself.

Feeley and Simon $(1992,452)$ claimed that a "new penology" had caused a shift away from "moral or clinical description of the individual" and toward "probabilistic calculations and statistical distributions applied to populations" in prison. These apparently distinct regimes of risk cannot remain separated in the legal realm, which is a chaotic world marked by a "halfhearted commitment to 
truth," in Valverde's memorable phrase $(2003,5)$. Any actuarial instrument demands clinical judgment; it must be wrapped in a subjective packaging if only because of its clinical context and the unavoidable need to interpret responses.

In parole hearings, a hybrid actuarial-diagnostic regime has therefore been established (Lynch 1998). The board is committed to producing a comprehensive risk assessment for each lifer, which is meant to be renewed every three years. Board-appointed psychologists are tasked with interviewing and assessing inmates. These interviews - euphemistically described as mere "conversations"include a review of an inmate's childhood history, criminal record, parole and probation history, alcohol and drug use, programming, and previous evaluations. Crucially, these assessments synthesize formal instruments with subjective evaluation. In one inmate's case, a previous psychologist had "offered the diagnosis of Alcohol Dependence in Controlled Environment, Adult Antisocial Personality Behavior, and noted Psychopathic Features on Axis II," leading the board to assign the inmate a "moderate risk" rating. The psychologist rated the inmate "in the moderate range on the PCL-R, and the moderate range on the HCR-20." In a more recent assessment and report, another psychologist had found the inmate to "be a low risk" if he were to be "released in the free community." The inmate's "mental health status" had "been gone over," including his "substance abuse history, which we talked about." The psychologist no longer 
gave a "diagnosis in the area of Major Mental Disorder, Personality Disorder," as the previous psychologist had done. In this way, psychologists deployed the diagnostic-evaluative categories of professional judgment as well as formalized actuarial instruments of assessment to forge a comprehensive "impression" of the inmate, distilled in one single output: low, moderate, or high risk.

The apparent objectivity of psychological science - the "pretend-scientific approach adopted by psychology" (Parker 2007, 26) — provides the board with a valuable source of expert discourse seemingly free from the entanglements of subjectivism (Turnbull and Hannah-Moffat 2009, 535-36). Risk assessments are a veritable "antipolitics machine" (Scott 2012, 111), making commissioners unassailable. So-called quantitative instruments of objectivized subjectivity provide state officials with the "vital protective cover" of seemingly apolitical neutrality (Scott 2012, 126). Evaluative judgments shot through with subjectivism are covered with the veneer of medical-statistical objectivity. Apparently sound, irreproachable categories of diagnosis, such as "psychopathy" or an "antisocial personality disorder," mask the long labor of constructing judgment on the basis of fleeting, chaotic, and asymmetrical clinical encounters that draw on multifarious bureaucratic sources and lopsided interviews by powerful psychologists with extremely marginalized individuals. Adding another layer of subjectivity, the board is not even committed to heeding the judgments of their 
own evaluators: a panel can "determine, at its discretion, what evidentiary weight to give psychological reports"; 9 and so even science must play the handmaid to carceral power.

In this way, risk becomes a multiscalar concept to the board, synthesizing a diverse array of inputs: psychological evaluations (composed of formalized actuarial instruments and subjective clinical impressions); disciplinary records (including $115 \mathrm{~s}, 128$-Bs, and gang membership reports); ${ }^{10}$ participation in rehabilitation (programming); work records; educational diplomas; remorse letters (signaling acceptance of responsibility and a sensitivity toward victims); bodily form (the intersection of age, muscular build, tattoos, and corporal posture producing an immediate impression of either danger or pacification); post-release plans (including familial support, employment plans, and transitional housing); and the actual "spontaneous" performance during the hearing. This last component — a performative display before the commissioners - is the point at which all those dimensions of risk meet and commingle, giving rise to a particular "field of forces" (Hawkins 2003, 187) in which discretionary judgment can be passed. Those who meet the board's evaluative standards are said to "perform well" and "possess insight," allowing the commissioners to "get comfortable" and ultimately, perhaps, grant inmates their freedom. Only those who are perceived not to pose a risk will obtain this admission. Risk is always the product of the 
conjoined entanglement of fact and value, mixing and melding subjective impressions and formalized instruments of evaluation (see Hannah-Moffat 2015).

As Bourdieu (2001, 8-9) noted, the notion of a "category" connotes both membership in a social group and a principle of perception and action. The latter tends to flow from the former; that is, members of social categories are equipped with the perceptual categories appropriate to and stemming from their category of belonging. Most commissioners are drawn from the mutually entangled worlds of law enforcement and corrections. In 2010 eight out of twelve commissioners shared a professional background in law enforcement, three had primarily worked in corrections, and one was a private attorney. By 2016 this balance had shifted slightly: four commissioners were drawn from the ranks of law enforcement, five had a correctional background, and three were former practicing attorneys. Law enforcement and corrections constitute the board's dominant professional categories, naturally imbuing its decisions with the logic and common sense inherent to and naturalized within those professions.

\section{Conclusion}

The board's default inclination to deny parole can be explained along three broad lines. First, commissioners are themselves products of a field of penality characterized by "law and order": the vast majority are drawn from the 
correctional system or policing apparatus, making them the preeminent bearers of a particular penal worldview that posits incarceration as the default societal response to crime, premised on a belief in the essential incorrigibility of many offenders. Second, commissioners are fundamentally risk-averse. When in doubt, it is always safer to err on the side of caution. Commissioners can be severely blamed for releasing one too many offenders, but only under the rarest conditions could they be blamed for releasing one too few offenders. This is due in part to the influences of political and media power that envelop their professional positions. If controversial inmates are granted parole, commissioners might find themselves in the midst of a media storm. Letting the wrong sort of inmate out of prison is liable to be sanctioned by the governor or state senate, both of which play an instrumental role in appointing and confirming the twelve commissioners who constitute the upper levels of the board. One commissioner was strongly criticized after granting parole to a member of the infamous 1960s Manson Family, a decision immediately met with highly unfavorable media reporting (e.g., Schram 2016); a few months later, that parole grant was rejected by the governor (Park 2016).

Finally, owing to the absence of durable social safety nets, commissioners seem genuinely concerned about releasing offenders into an unprotected community. One commissioner described lying awake at night worrying about whether the 
board had released a dangerous offender out into the community. "I always scan for my guys," the commissioner said, making a scrolling gesture on an imaginary phone, and he wonders whether "their" parolees would commit another violent crime. In a society ill-disposed toward former convicts and lacking comprehensive state provisions for parolees, denying parole seems attractive. In any case, as Werth (2011) has pointed out, there is little sign that the "reformed subjectivities" of parolees is ever fully recuperated by the state; even as inmates acquiesce, they continue to maintain a certain (inward) defiance and nonconformity.

One prison officer-whose job it was to provide security during the hearings, which really meant sitting quietly along the back wall and staring into space for however long the hearing lasted — told me about how his recent conversion to an evangelical brand of Christianity had changed his perception of the hearings. "I mean, I'm a Christian now, and I keep thinking, like, is this how it's gonna be when I get up there?" He waved his hand at the hearing room down the hallway. "Is there gonna be like a guy with a long list, going, OK, this is what you did here, and here," he said, as he mimicked a ledger, moving his index finger down a long list of entries. In this eschatological vision, he had homed in on something essential. These judgments partook of a long line of semitheological procedures of judgment whose aim was to engage in processes of veridiction (Foucault 2014), 
and whose truth-content was constantly being informed by notions of goodness and authenticity.

Inmates are caught in a world torn between the ubiquitous brutality of carceral austerity and the ritualistic formalism of a legal hearing. In their everyday lives, inmates must adopt a tough stance and build social alliances to avoid violence, abuse, and exploitation. In the parole hearing, however, and for the briefest of intervals during an otherwise lengthy, uninterrupted, decades-long existence behind bars, an inmate must temporarily shed his prison persona - the "yard face" of the carceral habitus (Caputo-Levine 2012) —and substitute for it a pose of contemplative reflection and irenic respectability. Few inmates are equipped with the social competence necessary to successfully navigate between these diametrically opposed realms. They lack experience in performing to the standards of the law, often fail to utter sentences in an appropriately formal register, and cannot successfully manage diglossia — the hardened linguistic register of the prison yard contra the legal formalism and psychological introspection demanded in the hearing room. In the words of one private defense attorney, "When you have a parole suitability hearing, you must be adequately prepared for your hearing. ...You must have a thorough file review. If you've been in prison for ten to fifteen years, the file can be quite voluminous, but you need to take the time and effort to review the file." 11 
This is undoubtedly sound advice, but it demands a particular linguistic and scholastic competence that is quite often thoroughly lacking among inmates. This observation is supported by the generally low levels of reading comprehension evidenced by many lifers according to the state's own scholastic aptitude tests (TABE scores). ${ }^{12}$ Eighteen TABE scores were available out of the twenty hearings observed, and they had an average score of 9.6. The board takes this to be the equivalent of a mid-ninth-grade level of reading and writing proficiency. A middle-school level of scholastic aptitude does not bode well for inmates' ability to manage the "voluminous" records of their legal and institutional histories or to engage in thorough file reviews, particularly given the very limited help most inmates receive from their (underpaid and overworked) state-appointed defense attorneys. Meanwhile, by comparison, commissioners are far more experienced and pride themselves on having "seen it all before" and having heard every ruse, line, and hustle. The commissioners are the high priests of the parole performance and inmates are their ill-equipped neophytes. To the former, hearings are routine occurrences; to the latter, they are extraordinary ceremonies.

Owing to a fundamental absence of hearing, many hearings are literally absurd, in the etymological sense of surdus, meaning deafness. They are often hearings without listening. Nevertheless, they continue in the long shadow cast by the 
penal regime of hyperincarceration (Wacquant 2009). The most difficult thing in the world is to describe the extraordinary ordinariness of social life (Bourdieu 1998a, 21). It is the routinization of the exceptionally quotidian that primarily characterizes the affectivity of parole hearings: heartrendingly agonistic, achingly dull, and tinged with the loud ideological overtones of moralizing individualization and responsibilization. Parole is often disavowed by a culture of punishment that emphasizes and elevates the hermetic capacities of the self-made man to lift himself up by his own bootstraps; and it is suffused with bureaucratic pathologies, institutional shortcomings, and societal deficiencies. In short, a parole hearing is a denial of the lessons of sociology.

\section{Notes}

This research was supported by a grant from the Norwegian Research Council (Grant No. 259888). I would like to thank the following individuals for their invaluable efforts in facilitating this research: Ritika Aggarwal, Bengt Andersen, Megan Comfort, Willy Pedersen, Sveinung Sandberg, Thomas Ugelvik, Ingvild Badhwar Valen-Sendstad, Loïc Wacquant, and Keith Wattley. I am also grateful to the journal's reviewers for their helpful comments and suggestions.

\footnotetext{
${ }^{1}$ In this article, individuals confined in prison are described as "inmates," which is an emic category pertaining to their legal and carceral status. This is not to say that they are not "sensate, suffering, skilled, sedimented, and situated creature[s] of flesh and blood" (Wacquant 2015, 2). That California prisons may form less of
} 
a "controlled environment" than commissioners purport is suggested by incidents of violence and sexual victimization (see Amnesty International 2012). In 2013 more than 29,000 inmates went on hunger strike in California, which also militates against the trope of a controlled environment.

${ }^{2}$ California Proposition 89, Governor's Parole Review (1988).

${ }^{3}$ These figures are drawn from Crime Victims Action Alliance (2016) and the author's own calculations. A handful of board parole grants that the state governor attempted to block were later approved by court order or by en banc decisions by the board. An en banc decision is a parole decision made by the board's collective body of commissioners.

${ }^{4}$ Brown v. Plata, 563 U.S. 493 (2011).

${ }^{5}$ In re Lawrence, 44 Cal. 4th 1181, 190 P.3d 535, 82 Cal. Rptr. 3d 169 (2008).

${ }^{6}$ In re Shaputis, 53 Cal.4th 192; 134 Cal.Rptr.3d 86; 265 P.3d 253 (2011), p. 221.

${ }^{7}$ Author's calculations, based on data from CDCR (2013b).

${ }^{8}$ Bourdieu's concept of principles of vision and division synthesizes multiple theoretical traditions, drawing on neo-Kantian concerns with constitutive categories (see Bourdieu 2014, 164-66), Durkheim's interest in collective representations, Weber's concern with allocations of social power, and a phenomenological sensitivity to the role of percepts in the constitution of the Lebenswelt. 
${ }^{9} 15$ CCR 2240d, California Code of Regulations, Title 15, Crime Prevention and Corrections.

${ }^{10}$ A "General Chrono" or a "128-B" (named after California Department of Corrections Form 128-B) is a written statement recording gang affiliation, potential "enemies" of the inmate, institutional placement score, and minor forms of misconduct, including a "refusal to comply with grooming standards," according to the California Code of Regulations (15 CCR 3000). A "Rule Violation Report" or a "115" (also known as CDC Form 115) covers misconduct "believed to be a violation of law" or "not minor in nature," including the "possession of five dollars or more without authorization," "refusal to perform work or participate in a program as ordered or assigned," "participation in a strike or work stoppage," and "self-mutilation or attempted suicide for the purpose of manipulation" (15 CCR 3315).

${ }^{11}$ Shouse Law Group Channel, "Preparation for a California Board of Parole Hearing," YouTube video, May 10, 2011, https://www.youtube.com/watch?v=399CBUBpKcU.

${ }^{12}$ The TABE score offers an assessment of scholastic aptitude and is usually used as an estimated indicator of the grade level of inmates; that is, approximating the level of schooling at which they are currently located. 


\section{References Cited}

Amnesty International. 2012. The Edge of Endurance: Prison Conditions in California's Security Housing Units. AMR 51/060/2012.

http://www.amnestyusa.org/sites/default/files/edgeofendurancecaliforniare port.pdf.

Beckett, Katherine, and Bruce Western. 2001. "Governing Social Marginality: Welfare, Incarceration, and the Transformation of State Policy.” In Mass Imprisonment: Social Causes and Consequences, edited by David Garland, 35-50. London: Sage.

Board of Parole Hearings. 2016. Board of Parole Hearings Workload Summary for the Calendar Year 2015. http://www.cdcr.ca.gov/BOPH/docs/LSTS_Workload_CY2015.pdf.

Bourdieu, Pierre. 1991. Language and Symbolic Power. Edited by John Thompson. Translated by Gino Raymond and Matthew Adamson. Cambridge: Polity Press.

—. 1998a. On Television. Translated by Priscilla Parkhurst Ferguson. New York: The New Press.

- 1998b. "Rethinking the State: Genesis and Structure of the Bureaucratic Field." In Practical Reason: On the Theory of Action, 35-63. Translated by Loïc Wacquant and Samar Farage. Stanford, CA: Stanford University Press. 
—. 2001. Masculine Domination. Translated by Richard Nice. Cambridge: Polity Press.

2014. On the State: Lectures at the Collège de France, 1989-1992.

Edited by Patrick Champagne, Remi Lenoir, Franck Poupeau and MarieChristine Riviere. Translated by David Fernbach. Cambridge: Polity Press. California Department of Corrections and Rehabilitation [CDCR]. 2013a. Lifer Parole Recidivism Report: California's Lifer Report Series, January 2013. http://www.cdcr.ca.gov/adult_research_branch/Research_Documents/FIN AL 0607 Lifer Parolee Recidivism 1 14 13.pdf. .2013b. Suitability Hearing Summary, April 29. http://www.cdcr.ca.gov/BOPH/docs/BPH_Hearing_Results_CY_1978_to 2012.pdf.

—. 2014. Prison Census Data as of December 31, 2013. http://www.cdcr.ca.gov/Reports_Research/Offender_Information_Service s_Branch/Annual/Census/CENSUSd1312.pdf.

-2015. Parole Suitability Hearing Handbook: Information for Victims and Their Families.

http://www.cdcr.ca.gov/victim_services/docs/bphhandbook.pdf. 2016. Lifer Parole Process.

http://www.cdcr.ca.gov/BOPH/lifer_parole_process.html. 
Caputo-Levine, Deirdre D. 2013. "The Yard Face: The Contributions of Inmate Interpersonal Violence to the Carceral Habitus.” Ethnography 14 (2): 16585.

Couzens, J. Richard, and Tricia A. Bigelow. 2017. The Amendment of the Three Strikes Sentencing Law. Judicial Council of California, May 2017. https://www.courts.ca.gov/documents/Three-Strikes-AmendmentCouzens-Bigelow.pdf.

Crime Victims Action Alliance. 2016. California Parole Board Statistics. http://www.cvactionalliance.com/ca-parole-board/california-parole-boardstatistics.

Downes, David. 1988. Contrasts in Tolerance: Post-War Penal Policy in the Netherlands and England and Wales. Oxford: Clarendon.

Elias, Paul. 2014. "Record Release of Lifers Plays 'Russian Roulette' with Public Safety: Victims’ Advocate.” NBCLosAngeles.com, February 25. http://www.nbclosangeles.com/news/local/Prisoners-PrisonOvercrowding-California-Gov-Jerry-Brown-Release-Lifers-Life-TermsPublic-Safety-247131961.html.

Emerson Robert M., Rachel I. Fretz, and Linda L. S. Shaw. 2011. Writing Ethnographic Fieldnotes. Chicago: University of Chicago Press. 
Feeley, Malcolm, and Jonathan Simon. 1992. "The New Penology: Notes on the Emerging Strategy of Corrections and Its Implications.” Criminology 30 (4): 449-74.

Foucault, Michel. 1995. Discipline and Punish: The Birth of the Prison. Translated by Alan Sheridan. New York: Vintage Books.

-2003. Abnormal: Lectures at the Collège de France, 1974-1975. Edited by Valerio Marchetti and Antonella Salomoni. Translated by Graham Burchell. London: Verso.

- 2014. Wrong-Doing, Truth-Telling: The Function of Avowal in Justice. Edited by Fabienne Brion and Bernard E. Harcourt. Translated by Stephen W. Sawyer. Chicago: The University of Chicago Press.

Garland, David. 2001. The Culture of Control: Crime and Social Order in Contemporary Society. Chicago: The University of Chicago Press.

Gilmore, Ruth. 2007. Golden Gulag: Prisons, Surplus, Crisis, and Opposition in Globalizing California. Berkeley: University of California Press.

Goodman, Philip. 2012. ““Another Second Chance’: Rethinking Rehabilitation through the Lens of California's Prison Fire Camps." Social Problems 59 (4): 437-58.

Hannah-Moffat, Kelly. 2015. "The Uncertainties of Risk Assessment: Partiality, Transparency, and Just Decisions." Federal Sentencing Reporter 27 (4): $244-47$. 
Hawkins, Keith. 2003. “Order, Rationality, and Silence: Some Reflections on Criminal Justice Decision-Making." In Exercising Discretion: DecisionMaking in the Criminal Justice System and Beyond, edited by Loraine Gelsthorpe and Nicola Padfield, 186-219. Cullompton, UK: Willan Publishing.

Hipolito Joey. 2009. "In re Lawrence: Preserving the Possibility of Parole for California Prisoners." California Law Review 97 (6): 1887-98.

Honneth, Axel. 1995. The Struggle for Recognition: The Moral Grammar of Social Conflicts. Cambridge: Polity Press.

Lynch, Mona. 1998. "Waste Managers? The New Penology, Crime Fighting, and Parole Agent Identity." Law \& Society Review 32 (4): 839-70.

—. "Rehabilitation as Rhetoric: The Ideal of Reformation in Contemporary Parole Discourse and Practices." Punishment \& Society 2 (1): 40-65.

Martinson, Robert. 1974. "What Works? Questions and Answers about Prison Reform." The Public Interest 35(Spring): 22-54.

Medlicott, Diana. 1999. "Surviving in the Time Machine: Suicidal Prisoners and the Pains of Prison Time." Time \& Society 8 (2): 211-30.

Nellis, Ashley. 2013. "Life Goes On: The Historic Rise in Life Sentences in America." The Sentencing Project, September. http://sentencingproject.org/wp-content/uploads/2015/12/Life-GoesOn.pdf. 
O’Malley, Pat. 1999. "Volatile and Contradictory Punishment.” Theoretical Criminology 3 (2): 175-96.

Park, Madison. 2016. “California Governor Rejects Parole for Ex-Manson Family Member." CNN, July 23. http://edition.cnn.com/2016/07/23/us/mansonfamily-leslie-van-houten-parole-denied/.

Parker, Ian. 2007. Revolution in Psychology: Alienation to Emancipation. London: Pluto Press.

Robinson, Gwen. 2008. “Late-Modern Rehabilitation: The Evolution of a Penal Strategy." Punishment \& Society 10 (4): 429-45.

Sarosy, Charlie. 2014. "Parole Denial Habeas Corpus Petitions: Why the California Supreme Court Needs to Provide More Clarity on the Scope of Judicial Review." UCLA Law Review 61:1134-91.

Schram, Jamie. 2016. "Manson Family Killer Granted Parole.” New York Post, April 14. http://nypost.com/2016/04/14/ex-manson-follower-details-grislymurders-at-parole-hearing/.

Scott, James C. 2012. Two Cheers for Anarchism. Princeton, NJ: Princeton University Press.

Shammas, Victor L. .2014. "The Pains of Freedom: Assessing the Ambiguity of Scandinavian Penal Exceptionalism on Norway's Prison Island.” Punishment \& Society 16 (1): 104-23. 
Simon, Jonathan. 2014. Mass Incarceration on Trial: A Remarkable Court Decision and the Future of Prisons in America. New York: The New Press.

Turnbull, Sarah, and Kelly Hannah-Moffat. 2009. "Under These Conditions: Gender, Parole and the Governance of Reintegration." British Journal of Criminology 49 (4): 532-51.

Valverde, Mariana. 2003. Law's Dream of a Common Knowledge. Princeton, NJ: Princeton University Press.

Wacquant, Loïc. 2009. Punishing the Poor: The Neoliberal Government of Social Insecurity. Durham, NC: Duke University Press.

—. 2010. "Class, Race, and Hyperincarceration in Revanchist America." Daedalus 139 (3): 74-90.

- 2015. "For a Sociology of Flesh and Blood." Qualitative Sociology 38 (1): $1-11$.

Ward, Tony, and Shadd Maruna. 2007. Rehabilitation: Beyond the Risk Paradigm. London: Routledge.

Wattley, Keith. 2013. “Insight into California's Life Sentence.” Federal Sentencing Reporter 25 (4): 1-5.

Weisberg, Robert, Debbie A. Mukamal, and Jordan D. Segal. 2011. Life in Limbo: An Examination of Parole Release for Prisoners Serving Life Sentences with the Possibility of Parole in California. Stanford, CA: 
Stanford Criminal Justice Center. http://law.stanford.edu/wpcontent/uploads/sites/default/files/publication/259833/doc/slspublic/SCJC \%20Lifer\%20Parole\%20Release\%20Sept\%202011.pdf.

Werth, Robert. 2011. “'I Do What I'm Told, Sort Of': Reformed Subjects, Unruly Citizens, and Parole." Punishment \& Society 16 (3): 329-46.

Western, Bruce. 2006. Punishment and Inequality in America. New York: Russell Sage Foundation.

Zimring, Franklin E., Gordon Hawkins, and Sam Kamin. 2001. Punishment and Democracy: Three Strikes and You're Out in California. Oxford: Oxford University Press. 